\title{
ANALISIS KEMAMPUAN BERPIKIR KREATIF KIMIA DITINJAU DARI ADVERSITY QUOTIENT, SIKAP ILMIAH DAN MINAT BELAJAR
}

\author{
FATWA PATIMAH NURSA'ADAH \\ fatwapatimah@yahoo.com
}

NOVRITA MULYA ROSA

Program Studi Pendidikan Matematika, FTMIPA Universitas Indraprasta PGRI

\begin{abstract}
Abstak.Tujuan dari penelitian adalah untuk menganalisis kemampuan berpikir kraetif kimia ditinjau dari adversity quotient, sikap ilmiah dan minat belajar. Subjek penelitian adalah mahasiswa Program Studi Pendidikan Matematika Universitas Indraprasta PGRI semester genap tahun akademik 2014/2015 , yang mengikuti perkuliahan Kimia Dasar II berjumlah 66 orang. Pemilihan kelas sampel menggunakan teknik multistage random sampling. Teknik pengumpulan data dilakukandengan melaksanakan tes kemampuan berpikir kreatif kimia berupa soal uraian. Data adversity quotient, sikap ilmiah dan minat belajar diperoleh dengan menggunakan angket skala sikap.Analisa data penelitian menggunakan korelasi dan regresi dengan bantuan program SPSS. Dari hasil penelitian disimpulkan bahwa ada pengaruh adversity quotient, sikap ilmiah dan minat belajar secara bersama-sama terhadap kemampuan berpikir kreatif dengan korelasi sebesar 0,359 dan koefisien determinasi sebesar 12,9\%. Pengujian Signifikasi Koefisien Regresi diperoleh nilai sig 0,034 dan $F_{\text {hitung }}=3,066$. Uji pengaruh masing-masing variabel diperoleh terdapat pengaruh adversity quotient terhadap kemampuan berpikir kreatif dengan nilai sig $=0,012$ dan $t_{\text {hitung }}=2,595$. Tidak terdapat pengaruh sikap ilmiah terhadap kemampuan berpikir kreatif dengan nilai sig $=0,646$ dan $t_{\text {hitung }}=-0,461$. Tidak terdapat pengaruh minat belajar terhadap kemampuan berpikir kreatif dengan nilai sig $=0,508$ dan $t_{\text {hitung }}=-0,666$.
\end{abstract}

\section{Kata kunci : kemampuan berpikir kreatif}

\begin{abstract}
The objective of this research is to analyze the chemical creative thinking in terms of adversity quotient, scientific attitude and interest in learning. Subjects were students of University Mathematics Education Indraprasta PGRI second semester of academic year 2014/2015, which follows the lecture Basic Chemistry II amounted to 66 people. Selection of sample classes using multistage random sampling technique. Data collection technique is done by carrying out chemical tests of creative thinking skills such as problem description. Data adversity quotient, scientific attitude and interest in learning obtained using attitude scale questionnaire. Data analysis technique use correlation and regression with SPSS. The conclusion is that there is the influence of adversity quotient, scientific attitude and interest in learning jointly on the ability to think creatively with a correlation of 0.359 and a coefficient of determination is $12.9 \%$. Significance testing Regression Coefficients obtained $\mathrm{F}_{\text {count }} \mathrm{sig}=0.034$ and 3.066. Test the effect of each variable there are significant adversity quotient obtained on the ability to think creatively with sig $=0.012$ and $t=2.595$. There is no scientific attitude influence on the ability to think creatively with sig $=0.646$ and $t=-0.461$. There is no interest in studying the effect on the ability to think creatively with $\mathrm{sig}=0.508$ and $\mathrm{t}=-0.666$.
\end{abstract}

Keywords : chemical creative thinking 


\section{PENDAHULUAN}

Daya kompetitif suatu bangsa salahsatunya ditentukan oleh kreativitas sumber daya manusianya. Kreativitas diperlukan pada setiap bidang kehidupan untuk mendesain sesuatu, mengkreasi perubahan, menyelesaikan masalah yang bertujuan untuk meningkatkan kualitas hidup. Dengan demikian pendidikan harus diarahkan untuk menghasilkan manusia yang berkualitas dan mampu bersaing, disamping memiliki budi pekerti yang luhur dan moral yang baik. Kemampuan pemecahan masalah, berpikir kritis dan berpikir kreatif merupakan hakekat tujuan pendidikan dan menjadi kebutuhan bagi mahasiswa untuk menghadapi dunia nyata (Santyasa,2004). Kreativitas merupakan produk dari kemampuan berpikir kreatif. Usaha pengembangan kemampuan berpikir kreatif mahasiswa, termasuk merupakan kebutuhan mengingat pentingnya peranan kreativitas.

Pembelajaran kimia bertujuan melatih cara berpikir dan bernalar dalam menarik kesimpulan, misalnya melalui kegiatan penyelidikan, mengeksplorasi, eksprimen, menunjukkan kesamaan, perbedaan, konsisten dan inkonsisten. Beberapa masalah yang dihadapi pada pembelajaran Kimia Dasar II di Program Studi Pendidikan Matematika, FTMIPA, Universitas Indraprasta PGRI adalah sebagai berikut. Pertama, keterampilan mahasiswa dalam memecahkan masalah masih rendah. Mahasiswa sering mengalami kegagalan dalam memecahkan masalah yang menuntut jawaban divergen. Mahasiswa cenderung menjawab pertanyaan hanya dengan menggunakan satu cara saja atau sesuai dengan yang dicontohkan dosen tanpa berusaha untuk mencari alternatif jawaban yang berbeda. Tingkat kegigihan mahasiswa dalam memecahkan masalah masih rendah sehingga berpengaruh terhadap kemampuan berpikir kreatif mereka. Kedua, Sikap Ilmiah mahasiswa masih belum berkembang, hal ini terlihat dari rasa ingin tahu tentang alam semesta masih sedikit, masih gegabah dalam menyelesaikan permasalahan dan dalam penarikan kesimpulan belum didukung bukti-bukti yang kuat. Ketiga, minat belajar mahasiswa pada mata kuliah Kimia Dasar II masih rendah. Hal ini tampak pada beberapa indikator, yaitu mahasiswa hanya memanfaatkan sumber informasi yang terbatas, mahasiswa jarang bertanya selama proses pembelajaran dan jarang mendiskusikan materi yang telah dipelajari, indikator lainnya adalah waktu belajar di kelas dengan durasi yang cukup panjang terkadang membuat mahasiswa tidak dapat mempertahankan semangatnya selama pembelajaran, selain itu mahasiswa cenderung memanfaatkan waktu yang ada di kampus tanpa harus mengembangkan materi tambahan untuk memperluas wawasan mahasiswa di luar jam kuliah.

Oleh karena itu, perlu dilakukan kajian mengenai faktor-faktor yang dapat mempengaruhi kemampuan berpikir kreatif. Perkembangan berpikir kreatif pada mahasiswa dipengaruhi oleh faktor intern dan ekstern. Faktor intern adalah faktor yang berasal dari mahasiswa contohnya : kecerdasan, bakat, ketahanmalangan (Adversity Quotient), minat, dan sikap. Faktor ekstern adalah faktor yang berasal dari luar mahasiswa seperti lingkungan keluarga, kampus dan masyarakat.

\section{TINJAUAN PUSTAKA}

\section{Hakikat Kemampuan Berpikir Kreatif Kimia}

Berpikir sebagai suatu kemampuan mental seseorang yang sangat penting, salah satunya adalah berpikir kreatif. Berpikir kreatif merupakan perwujudan dari berpikir tingka ttingg i(high order thingking). Menurut (Filsaime, 2008), berpikir kreatif adalah proses berpikir yang memiliki ciri-ciri kelancaran (fluency), keluwesan (flexibility), keaslian atau originalitas (originality) dan merinci atau elaborasi (elaboration). Kelancaran adalah kemampuan mengeluarkan ide atau gagasan yang benar sebanyak mungkin secara jelas. Keluwesan adalah kemampuan untuk mengeluarkan banyak ide 
atau gagasan yang beragam dan tidak monoton dengan melihat dari berbagai sudut pandang. Originalitas adalah kemampuan untuk mengeluarkan ide atau gagasan yang unik dan tidak biasanya, misalnya yang berbeda dari yang ada di buku atau berbeda dari pendapat orang lain. Elaborasi adalah kemampuan untuk menjelaskan faktor-faktor yang mempengaruhi dan menambah detail dari ide ataugagasannyasehinggalebihbernilai.

Dari pendapat para ahli diatas maka dapat disimpulkan bahwa kemampuan berpikir kreatif adalah ketrampilan memunculkan ide atau gagasan dalam memecahkan masalah dengan cara yang beragam dan berbeda dengan yang telah ada sebelumnya namun bisa juga modifikasi dari cara yang lama dengan prinsip kebaruan.

\section{Hakikat Adversity Quotient}

Kesuksesan merupakan harapan dari setiap orang. Dalam mencapai kesuksesan, butuh perjuangan yang tidak mudah, pasti akan selalu ada kesulitan yang datang. Stoltz (Bukhari, 2011: 8394)"adversity" berarti kemalangan, kesulitan, dan penderitaan. Banyak orang yang dengan mudah takluk kepada berbagai kesulitan yang menghadang, Sebagian dari mereka mencoba untuk menghadapinya tetapi mundur teratur oleh terjalnya sebuah penderitaan. Menurut Stoltz (Hans, 2006: 91) "Adversity quotient adalahkegigihan dalam mengatasi segala rintangan dalam mendaki puncak sukses yang diinginkan".Ginanjar (Bayani dan Hafizhoh, 2011: 69), "dengan Adversity quotient seseorang bagai diukur kemampuannya dalam mengatasi setiap persoalan hidup untuk tidak berputus asa". Sinamo (2010:33): "Kecerdasan Adversitas adalah sebuah daya kecerdasan budi-akhlakiman manusia untuk menundukan tantangan-tantangannya, menekuk kesulitankesulitannya, dan meringkus masalah-masalahnya sekaligus mengambil keuntungan dari kemenangan-kemenangan itu". Berdasarkan teori-teori diatas, dapat disimpulkan bahwa Adversity quotient dapat didefinisikan sebagai kecerdasan individu dalam menghadapi kesulitan-kesulitan, hambatan-hambatan maupun tantangan dalam hidup.

\section{Hakikat Sikap Ilmiah}

Menurut Sudijono (2008:27), sikap merupakan bagian dari tingkah laku manusia sebagai gejala atau gambaran kepribadian yang memancar keluar. Dengan demikian sikap merupakan tingkah laku atau perbuatan akibat reaksi seseorang terhadap orang lain atau benda tertentu.Menurut Harlen dalam Fakhruddin (2010:19) ada 9 aspek sikap ilmiah yaitu : Sikap ingin tahu, sikap ingin mendapatkan sesuatu yang baru, sikap kerjasama, sikap tidak putus asa, sikap tidak berprasangka, sikap jujur, sikap bertanggung jawab, sikap berfikir bebas, dan sikap kedisiplinan diri.Sikap ilmiah diartikan sebagai suatu kecenderungan, kesiapan, kesediaan, seseorang untuk memberikan respon/tanggapan/tingkah laku secara ilmu pengetahuan dan memenuhi syarat (hukum) ilmu pengetahuan yang telah diakui kebenarannya. Sikap ilmiah merupakan pendekatan tertentu untuk memecahkan masalah, menilai ide dan informasi untuk membuat keputusan. Pengembalian keputusan berdasarkan bukti yang telah dikumpulkan dan dievaluasi secara objektif. Diperlukan juga sikap kritis berdasarkan bukti yang relevan. Orang yang melakukan prosedur ini dikatakan memiliki sikap ilmiah. Sikap ilmiah memiliki peran penting dalam mengembangkan kecakapan ilmiah. Setiap individu yang memiliki sikap ilmiah, memiliki kualitas seperti realistis memiliki perhatian terhadap lingkungan sekitar, menghindari generalisasi yang didasarkan pada fenomena dan tidak mempercayai keyakinan dogmatis (Anagun and yasar, 2009)

\section{Hakikat Minat Belajar}

Minat adalah suatu rasa suka dan rasa ketertarikan pada suatu hal atau aktivitas, tanpa ada yang menyuruh dan cenderung untuk memberikan perhatian yang lebih besar 
terhadap hal atau aktivitas tersebut (Slameto, 2010:180). Secara sederhana minat (interest) berarti kecenderungan dan kegairahan yang tinggi atau keinginan yang besar terhadap sesuatu. (Syah, 2008:136). Menurut Reber yang dikutip Syah (2008 : 136), minat banyak tergantung pada faktor-faktor internal lainnya seperti ; pemusatan perhatian, keingintahuan, motivasi dan kebutuhan. Menurut Putra (2011:21), minat yang kuat akan menimbulkan usaha yang gigih serius dan tidak mudah putus asa dalam menghadapi tantangan. Jika seseorang siswa memiliki rasa ingin belajar, ia akan cepat dapat mengerti dan mengingatnya. Fungsi minat bagi kehidupan anak, salah satunya yaitu minat sebagai pendorong tenaga yang kuat serta prestasi selalu dipengaruhi oleh jenis dan intensitas minatnya.

Seorang mahasiswa yang memiliki minat belajar terhadap mata kuliah tertentu maka dia akan merasa senang mempelajari materi kuliah. Minat belajar dapat ditumbuhkembangkan dengan menggunakan berbagai cara salah satunya dengan mengkondisikan suasana pembelajaran di dalam kelas. Pembelajaran yang menarik akan membangkitkan minat mahasiswa dalam mendalami materi kuliah.

\section{METODE}

Penelitian dilaksanakan pada Program Studi Pendidikan Matematika Universitas Indraprasta PGRI, Jakarta Selatan. Populasi pada penelitian ini adalah mahasiswa yang terdaftar pada semester genap tahun akademik 2014/2015 yang mengikuti mata kuliah Kimia Dasar II.Untuk pengambilan sampel pada penelitian ini diambil paramahasiswa yang tergabung dalam populasi terjangkau. Dalam pengambilan sampel peneliti mengambil teknik sampling multi stage random sampling sehingga diperoleh 66 responden sebagai sampel.

Penelitian ini menggunakan metode penelitian survey dengan analisis korelasiregresi guna melihat pengaruh antara variabel kriterium $(\mathrm{Y})$ dan variabel prediktor $\left(\mathrm{X}_{1}\right)$ dan $\left(\mathrm{X}_{2}\right)$ dan $\left(\mathrm{X}_{3}\right)$ secara bersamaan dan parsial. Desain penelitiannya dapat dilihat pada gambar1berikut:

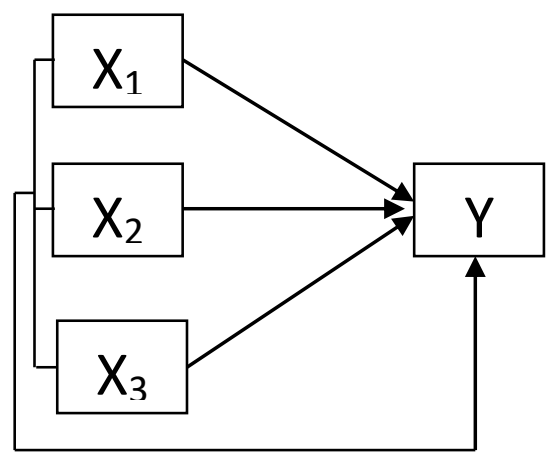

\section{Gambar 1. Konstelasi Pengaruh antar Variabel Penelitian}

Keterangan :

$\mathrm{X}_{1} \quad$ : Adversity Quotient

$\mathrm{X}_{2} \quad$ : Sikap Ilmiah

$\mathrm{X}_{3} \quad$ : Minat Belajar

Y : Kemampuan Berpikir Kreatif Kimia

Teknik pengumpulan data dalam penelitian ini menggunakan metode tes untuk melihat kemampuan berpikir kreatif kimia. Data adversity quotient, sikap ilmiah dan minat belajar diperoleh dengan menggunakan angket skala sikap.Pada penelitian ini akan 
diteliti kemampuan berpikir kreatif kimia mahasiswa dalam memecahkan masalah yang berkaitan dengan koloid.

Uji Persyaratan analisis meliputi uji normalitas yang digunakan adalah analisisKolmogorov Smirnov, uji multikolinieritas dilakukan dengan menggunakan analisistolerance dan VIF dan uji linearitas. Hipotesis dalam penelitian diuji dengan menggunakan uji statistik korelasi-regresi. Semua uji dilakukan menggunakan program SPSS.

\section{HASIL DAN PEMBAHASAN \\ Deskripsi Data}

Data variabel Adversity Quotient, didapat skor rata-rata 91,42 dengan standar deviasi 8,675., median 91,50 skor minimun 76 dan maksimum 109. Data variable Sikap Ilmiah didapat skor rata-rata 99,79 dengan standar deviasi 7,945., median 98,50 skor minimun 82 dan maksimum 119. Data variabelminatbelajardidapat skor rata-rata 89,08 dengan standar deviasi 8,265., median 88,00 skor minimun 70 dan maksimum 120. Data Kemampuan Berpikir Kreatif Kimia didapat skor rata-rata 19,86 dengan standar deviasi 3,229., median 20 skor minimun 12 dan maksimum 26. Hasil temuan ini menunjukkan bahwa data variabel Adversity Quotient, Sikap Ilmiah, Minat Belajar dan Kemampuan Berpikir Kreatif Kimia cukup bervariasi. Dengan demikian dapat dikatakan bahwa Adversity Quotient, Sikap Ilmiah, Minat Belajar dan Kemampuan Berpikir Kreatif Kimia mahasiswa memiliki karakteristik yang beragam.

\section{Pengujian Persyaratan Analisis}

1. UjiNormalitas

Persyaratan dalam menganalisis data yang pertama dilakukan adalah uji normalitas, uji ini dilakukan dengan menggunakan perhitungan SPSS 16.0. berdasarkan hasil SPSS, terlihat bahwa nilai sig Adversity Quotient $(0,311>0,05)$, Sikap Ilmiah $(0,585$ $>0,05)$, Minat Belajar $(0,255>0,05)$ dan Kemampuan Berpikir Kreatif Kimia $(0,407$ $>0,05)$ yang artinya data variabel Adversity Quotient, Sikap Ilmiah, Minat Belajar dan Kemampuan Berpikir Kreatif Kimia mahasiswa berdistribusi normal (0,480 $>0,05$ ).

2. Uji Linieritas

Persyaratan dalam menganalisis data yang kedua dilakukan adalah ujilinieritas, uji ini dilakukan dengan menggunakan perhitungan SPSS 16.0. berdasarkan hasil SPSS, terlihat bahwa nilai sig Adversity Quotient $(0,350>0,05)$, Sikap Ilmiah $(0,678>0,05)$, Minat Belajar $(0,084>0,05)$ yang artinya masing-masing data variabel Adversity Quotient, Sikap Ilmiah, Minat Belajar terhadap variabel kemampuan berpikir kreatif kimia (Y) terdapat hubungan linear.

3. Uji Multikolinearitas

terlihat bahwa nilai tolerance untuk masing-masing variabel Adversity Quotient $(0,504$ $>0,1)$, Sikap Ilmiah $(0,374>0,1)$, Minat Belajar $(0,631>0,1)$ dan nilai VIF untuk masing-masing variabel Adversity Quotient (1,985 < 10), Sikap Ilmiah $(2,675<10)$, Minat Belajar $(1,585<10)$ yang artinya data dari semua variabel tidak terjadi multikolinieritas.

\section{Pengujian Hipotesis}

Dalam penelitian ini terdapat 4 hipotesis yang diuji dengan menggunakan bantuan komputer SPSS versi 16.0. Pengujian hipotesis menggunakan regresi ganda, data yang digunakan dalam penelitian ini adalah data Adversity Quotient $\left(\mathrm{X}_{1}\right)$, sikap ilmiah $\left(\mathrm{X}_{2}\right)$ 
dan kemampuan berpikir kreatif kimia (Y). Hipotesis penelitian ini secara bertur-turut adalah:

Berdasarkan SPSS, bahwa koefisien korelasi ganda pengaruh variabel bebas Adversity Quotient dan sikap ilmiah secara bersama-sama terhadap kemampuan berpikir kreatif kimia adalah sebesar 0,359. Dari perhitungan tersebut diperoleh bahwa koefisien korelasi tersebut signifikan, dengan kata lain bahwa terdapat pengaruh Adversity Quotient dan sikap ilmiah secara bersama-sama terhadap kemampuan berpikir kreatif kimia.Sedangkan koefisien determinasinya sebesar 12,9 \% menunjukkan bahwa besarnya kontribusi Adversity Quotient, sikap ilmiahdan minat belajar secara bersama-sama terhadap kemampuan berpikir kreatif kimia, sisanya $87,1 \%$ karena pengaruh faktor lain.Nilai sig $=$ 0,034 dan $F_{\text {hitung }}=3,066$ sedangkan $F_{\text {tabel }}=2,768$ karena nilai sig $<0,05$ dan $F_{\text {hitung }}>F_{\text {tabel}}$, maka $\mathrm{H}_{0}$ diterima, berarti $\mathrm{H}_{1}$ tidak dapat diterima. Artinya, terdapat pengaruh yang signifikan variabel Adversity Quotient, sikap ilmiah dan minat belajar secara bersama-sama terhadapkemampuan berpikir kreatif kimia (Y).

Berdasarkan hasilperhitungan SPSS, nilai sig Adversity Quotient $=0,012$ dan $t_{\text {hitung }}=2,595$ sedangkan $t_{\text {tabel }}=1,999$ karena nilai sig $<0,05$ dan $t_{\text {hitung }}>t_{\text {tabel }}$, maka $\mathrm{H}_{0}$ tidak dapat diterima, berarti $\mathrm{H}_{1}$ diterima. Artinya, terdapat pengaruh yang signifikan variabel Adversity Quotient terhadapkemampuan berpikir kreatif kimia (Y).

Berdasarkan hasilperhitungan SPSS, nilai sigSikapIlmiah $=0,646$ dan $t_{\text {hitung }}=$ 0,461 sedangkan $t_{\text {tabel }}=1,999$ karena nilai sig $>0,05$ dan $t_{\text {hitung }}<t_{\text {tabel }}$, maka $\mathrm{H}_{0}$ diterima, berarti $\mathrm{H}_{1}$ tidak dapat diterima. Artinya, tidak terdapat pengaruh yang signifikan variabel sikap ilmiah terhadapkemampuan berpikir kreatif kimia (Y).

Berdasarkan hasilperhitungan SPSS, nilai sigMinatBelajar $=0,508$ dan $t_{\text {hitung }}=$ 0,461 sedangkan $t_{\text {tabel }}=1,999$ karena nilai sig $>0,05$ dan $t_{\text {hitung }}<t_{\text {tabel }}$, maka $\mathrm{H}_{0}$ diterima, berarti $\mathrm{H}_{1}$ tidak dapat diterima. Artinya, tidak terdapat pengaruh yang signifikan variabel minat belajar terhadapkemampuan berpikir kreatif kimia $(\mathrm{Y})$.

\section{Pembahasan}

1. Pengaruh Adversity Quotient $\left(\mathrm{X}_{1}\right)$, Sikap ilmiah $\left(\mathrm{X}_{2}\right)$ dan Minat belajar $\left(\mathrm{X}_{3}\right)$ secara bersama-sama dengan Kemampuan berpikir kreatif kimia (Y).

Berdasarkan hasilanalisis data SPSS, terlihat bahwa koefisien korelasi ganda pengaruh variabel bebas Adversity Quotient, sikap ilmiah dan minat belajar secara bersama-sama terhadap kemampuan berpikir kreatif kimia adalah sebesar 0,359. Dari perhitungan tersebut diperoleh bahwa koefisien korelasi tersebut signifikan, dengan kata lain bahwa terdapat pengaruh Adversity Quotient, sikap ilmiah dan minat belajar secara bersama-sama terhadap kemampuan berpikir kreatif kimia. Sedangkan koefisien determinasinya sebesar 12,9 \% menunjukkan bahwa besarnya kontribusi Adversity Quotient, sikap ilmiah dan minat belajar secara bersama-sama terhadap kemampuan berpikir kreatif kimia, sisanya 87,1\% karena pengaruh faktor lain.

Menurut Wardiana (2014) Semakin tinggi AQ yang dimiliki sesorang maka semakin tinggi pula ketahanmalangan yang dimiliki seseorang tersebut jika mendapatkan kesulitan dalam hidupnya.. Seseorangyang memiliki AQ lebih tinggi, tidak dengan mudah menyalahkan pihak lain atas persoalanyang dihadapinya melainkan bertanggung jawab untuk menyelesaikan masalah. Mereka tidak mudah mengeluh dan tidak mudah berputus asa walau kondisi seburuk apapun. Justrusebaliknya, dengan segala keterbatasannya, mereka mampu berpikir, bertindak dan menyiasati diri untuk maju terus. Sebaliknya, rendahnya AQ seseorang adalah tumpulnya daya tahan hidup. Mengeluh sepanjang hari tatkala menghadapi persoalan dan sulit untuk melihat hikmah di balik semua permasalahan yang dihadapinya. 
Kimia mempunyai sifat khas yakni berkaitan dengan ide abstrak yang diberi simbol. Sebagian mahasiswa beranggapan kimia dasar 2 merupakan mata kuliah yang sulit dikarenakan namyak konsep abstrak yang terdapat pada kimia.Disinilah potensi $A Q$ sangat dibutuhkan dalam belajar kimia. Belajar pada dasarnya adalah mengatasi kesulitan. Mengalami kesulitan, berarti seseorang masih diberi kesempatan untuk mengasah kembali kepekaan perasaan, ketajaman pikiran, dan kecerdasan (Ronnie,2006). Bukankah Seseorang dapat bertahansampai saat ini, salah satunya disebabkan karena telah menghadapi banyak sekali tantangan hidup di masa lalu.

Pengetahuan kimia diperoleh dan dikembangkan berdasarkan eksperimen untuk mencari jawaban atas pertanyaan apa, mengapa, dan bagaimana gejala-gejala alam khususnya yang berkaitan dengan komposisi, struktur, sifat, transformasi, dinamika dan energetika zat yang melibatkan keterampilan dan penalaran. Proses penemuan pengetahuan tersebut membutuhkan ketekunan dan pantang menyerah yang merupakan bagian dari Adversity Quotient. Sikap ilmiah dan minat belajar juga menjadi salah satu faktor pendukung dalam proses penemuan pengetahuan tersebut. Sikap ilmiah diperlukan oleh mahasiswa dalam memahami ataupun menemukan pengetahuan yang diantaranya dapat terlihat dari sikap ingin tahu dan luwes atau terbuka dengan gagasan ilmiah. Sedangkan minat belajar akan membuat seseorang lebih antusias dan peduli terhadap ilmu kimia. Sehingga mahasiswa akan berusaha menyelesaikan persoalan kimia dengan kreatifitas berpikir yang dimilikinya.

Berdasarkan temuan penelitian, diperoleh bahwa Adversity Quotient, sikap ilmiah dan minat belajar memberikan pengaruh yang signifikan dengan Kemampuan berpikir kreatif kimia mahasiswa. Atau dengan katalain dapat dikatakan bahwa apabila kemampuan berpikir kreatif kimia ingin ditingkatkan secara optimal, maka perlu peningkatan Adversity Quotient, sikap ilmiah dan minat belajar yang tinggi. Dengan Adversity Quotient, sikap ilmiah dan minat belajar yang bagus akan dapat meningkatkan proses pembelajaran yang lebih baik yang berdampak pada peningkatan kemampuan berpikir kreatif kimia.

\section{Pengaruh Adversity Quotient $\left(\mathrm{X}_{1}\right)$ dengan Kemampuan berpikir kreatif $\operatorname{kimia}(\mathrm{Y})$}

Berdasarkan hasil analisis data SPSS versi 16.0 dapat diketahui bahwa Adversity Quotient memiliki hubungan dengan Kemampuan berpikir kreatif kimia yang ditandai dengan perolehan hasil pengujian hipotesis nilai sig $=0,012$ dan $\mathrm{t}_{\text {hitung }}=$ 2,595 sedangkan $\mathrm{t}_{\text {tabel }}=1,999$ karena nilai sig $<0,05$ dan $\mathrm{t}_{\text {hitung }}>\mathrm{t}_{\text {tabel }}$, , maka $\mathrm{H}_{0}$ tidak dapat diterima, berarti $\mathrm{H}_{1}$ diterima. Artinya, terdapat pengaruh yang signifikan variabel Adversity Quotient terhadapkemampuan berpikir kreatif kimia (Y).

Berdasarkan Stoltz (2000) menyatakan bahwa orang sukses dalam belajar, adalah orang yang memiliki $A Q$ tinggi. Kesulitan baginya justru membuatnya menjadi pribadi pantang menyerah. Mereka mampu mengubah kesulitan menjadi peluang. Mereka adalah orang optimis yang memandang kesulitan bersifat sementara dan bisa diatasi. Faktor dominan pembentuk $A Q$ adalah sikap pantang menyerah. Sikap inilah yang perlu ditanamkan kepada setiap mahasiswa dalam belajar kimia. Kecerdasan ini menyangkut kemampuan seseorang untuk tetap gigih dan tegar dalam kesulitan dan penderitaan demi mencapai cita-cita. Saatnya membangun cara pandang mahasiswa bahwa kesulitan adalah bagian dari pertumbuhan menuju kemandirian melalui kegigihan dan ketekunan. Kesulitan bukan disingkirkan dari hadapan, melainkan keberanian perlu ditumbuhkan dalam diri untuk menghadapi kesulitan dalam belajar.Sehingga, dapat dikatakan bahwa apabila kemampuan berpikir kreatif kimia ingin ditingkatkan secara optimal, maka perlu peningkatan Adversity Quotient. 


\section{Pengaruh Sikap ilmiah $\left(X_{2}\right)$ dengan Kemampuan berpikir kreatif kimia} (Y)

Berdasarkan hasil analisis data SPSS versi 16.0 terlihat bahwa nilai sig $=0,646$ dan $t_{\text {hitung }}=-0,461$ sedangkan $\mathrm{t}_{\text {tabel }}=1,999$ karena nilai sig $>0,05$ dan $\mathrm{t}_{\text {hitung }}<\mathrm{t}_{\text {tabel }}$, maka $\mathrm{H}_{0}$ diterima, berarti $\mathrm{H}_{1}$ tidak dapat diterima. Artinya, tidak terdapat pengaruh yang signifikan variabel sikap ilmiah terhadapkemampuan berpikir kreatif kimia (Y). Menurut Harlen dalam Fakhruddin (2010:19) ada 9 aspek sikap ilmiah yaitu : Sikap ingin tahu, sikap ingin mendapatkan sesuatu yang baru, sikap kerjasama, sikap tidak putus asa, sikap tidak berprasangka, sikap jujur, sikap bertanggung jawab, sikap berfikir bebas, dan sikap kedisiplinan diri.

Pada penelitian ini, tidak ditemukan pengaruh variabel sikap ilmiah terhadap kemampuan berpikir kreatif kimia. Kemungkinan penyebabnya adalah dikarenakan sikap ilmiah mahasiswa yang belum terbentuk dengan baik. Pembentukan sikap ilmiah dapat dilakukan melalui pembelajaran yang melibatkan praktikum. Kegiatan praktikum melatih mahasiswa untuk mengembangkan sikap ingin tahu, sikap ingin mendapatkan sesuatu yang baru, sikap tidak putus asa, dan sikap berfikir bebas yang merupakan bagian dari sikap ilmiah. Dalam penelitian ini, peneliti hanya mengukur sikap ilmiah yang sudah ada dalam diri mahasiswa, tanpa adanya perlakuan dalam pembentukan sikap ilmiah itu sendiri, dikarenakan pembentukan sikap ilmiah membutuhkan waktu yang tidak sebentar. Ketika sikap ilmiah sudah terbentuk, maka akan mendukung kemampuan berpikir kreatif mahasiswa. Oleh karena itu, hasil penelitian ini diperoleh tidak terdapatnya pengaruh antara sikap ilmiah terhadap kemapuan berpikir kreatif mahasiswa.

\section{Pengaruh Minat Belajar $\left(X_{3}\right)$ dengan Kemampuan berpikir kreatif kimia} (Y)

Berdasarkan hasil analisis data SPSS versi 16.0 terlihat bahwa nilai sig $=0,508$ dan $t_{\text {hitung }}=-0,666$ sedangkan $\mathrm{t}_{\text {tabel }}=1,999$ karena nilai sig $>0,05$ dan $\mathrm{t}_{\text {hitung }}<\mathrm{t}_{\text {tabel }}$, maka $\mathrm{H}_{0}$ diterima, berarti $\mathrm{H}_{1}$ tidak dapat diterima. Artinya, tidak terdapat pengaruh yang signifikan variabel minat belajar terhadapkemampuan berpikir kreatif kimia (Y). Menurut Syah (2008:136) minat berarti kecenderungan dan kegairahan yang tinggi atau keinginan yang besar terhadap sesuatu. Dalam penelitian ini, ditemukan tidak terdapat pengaruh antara minat belajar terhadap kemampuan berpikir kreatif mahasiswa. Seseorang yang memiliki minat belajar tinggi, belum tentu memiliki kemampuan berpikir kreatif yang tinggi. Hal ini disebabkan kepekaan mahasiswa terhadap permasalahan kimia tidak muncul jelas karena tidak ada rangsangan yang disediakan dalam masalah serta tantangan yang diberikan oleh dosen, sehingga minat mahasiswa terhadap penyelesaian permasalahan kimia kurang. Sedangkan secara teoritis, minat dapat memicu individu meneruskan upaya untuk melakukan kegiatan observasi, eksplorasi sehingga dapat memunculkan gagasan yang beragam. Karena tidak adanya keberagaman gagasan, kemampuan mahasiswa untuk menghasilkan ideide yang tidak umum dan menyelesaikan masalah dengan cara yang tidak umum dalam penelitian masih minim.

\section{PENUTUP}

\section{Simpulan}

Dari Penelitian ini disimpulkan bahwa:

1. Terdapat pengaruh antara Adversity Quotient, Sikap Ilmiah dan Minat Belajar secara bersama-sama terhadap kemampuan berpikir kreatif kimia. 
2. Terdapatpengaruh Adversity Quotient terhadap kemampuan berpikir kreatif kimia.

3. Tidak terdapatpengaruh sikap ilmiah terhadap kemampuan berpikir kreatif kimia.

4. Tidak terdapatpengaruh minat belajar terhadap kemampuan berpikir kreatif kimia.

Saran

diantaranya:

Dari hasilpenelitiandankondisi yang adadapatdisampaikanbeberapa saran

1. Hendaknya dalam proses pembelajaran kimia, dosen dapat merancang dan mengembangkan adversity quotient, sikap ilmiah, dan minat belajar yang dapat membantu mahasiswa untuk belajar dan mampu memecahkan masalah sehingga dapat mengembangkan kemampuan berpikir kreatif mahasiswa.

2. Pembentukan sikap ilmiah perlu dipersiapkan dengan baik oleh dosen sehingga dapat melibatkan mahasiswa aktif secara langsung dalam pembelajaran khususnya dalam praktikum kimia

3. Kepadapenelitidanpemerhati pendidikan khususnya bidang pendidikan kimia. Karena penelitian ini baru sampai mengangkat pengaruh adversity quotient, sikap ilmiah dan minat belajar terhadap kemampuan berpikir kreatif kimia, maka peneliti menyarankan kiranya para peneliti tersebut dapat melanjutkan penelitian pasca penelitian ini. Hal ini penting agar hasil penelitian ini bermanfaat sebagai penyeimbang teori maupun sebagai reformasi terhadap dunia pendidikan.

\section{DAFTAR PUSTAKA}

Anagun, S.S., and Yasar, S. 2009. Reliability and validity studies of the science and technology course scientific attitude scale. Journal of Turkish Science Education, 6 (2): 43-45.

Bayani, Irma dan Hafizhoh Nur. 2011. Hubungan antara adversity quotient dan dukungan sosial dengan intensi untuk pulih dari ketergantungan narkotika alkohol psikotropika dan zat adiktif (NAPZA) pada penderita di wilayah Bekasi Utara Lembaga Kasih Indonesia. Jurnal Soul, 4 (2), 64-83. Diunduh http://www.ejournal-unisma.net/ojs/index.php/soul/article/view/606. Diakses 30 Sepetember 2016.

Candisa, I.M. 2006. Mengajar Siswa yang Beragam dengan Aneka Cara. http://www. balipost.co.id/ Diakses 30 September 2016.

Fakhruddin, Elva dan Syahril. 2010. Sikap ilmiah siswa dalam pembelajaran fisika dengan penggunaan media komputer melalui model kooperatif tipe STAD pada siswa kelas X3 SMA Negeri 1 Bangkinang Barat. Jurnal Geliga Sain, 4 (1): $18-22$.

Filsaime, D. K. 2008. Menguak Rahasia Berpikir Kritis dan Kreatif. Jakarta. Prestasi Pustaka.

Hans, Jen Z.A. 2006. Strategi Pengembangan Diri. Jakarta: Personal Development Training.

Laksomono, H.K. 2006. Jiwa "Climber" Pengusaha. http://www.paramuslim.com/ Diakses 30 September 2016.

Putra, Djodi Restyo. 2011. Studi Komparasi Penggunaan Metode CeramahDan Diskusi Terhadap Minat dan Prestasi Belajar Siswa dalam Pembelajaran PKN di SMPN 3 Prambanan Sleman. Yogyakarta:Universitas Negeri Yogyakarta.

Santyasa, I. W. 2004. Model Problem Solving dan Reasoning sebagai alternatif Pembelajaran Inovatif. Makalah. Disajikan dalam Konvensi Nasional Pendidikan Indonesia V. Bali : IKIP Negeri Singaraja. 
Sinamo, Jansen. 2010. 8 Etos Keguruan. Jakarta: Institut Darma Mahardika.

Slameto. 2010. Belajar dan Faktor-Faktor Yang Mempengaruhi. Jakarta:Rineka Cipta.

Sudijono, Anas. 2008. Pengantar Evaluasi Pendidikan. Jakarta : PT Raja Grafindo Persada.

Syah, Muhibbin. 2008. Psikologi Pendidikan dengan Pendekatan Baru. Bandung : PT. Remaja Rosdakarya. Cet.ke - 14 .

Wardiana, I Pt Arya, dkk. 2014. Hubungan antara Adversity Quotient dan Minat Belajar dengan Prestasi Belajar Matematika pada Siswa Kelas V SD di Kelurahan Pedungan. Jurnal Mimbar PGSD, 2 (1). 